\title{
Notes on the Occurrence of Tintinnid Ciliates, and the Nasselarian Radiolarian Amphimelissa setosa of the Marine Microzooplankton, in the Chukchi Sea (Arctic Ocean) Sampled each August from 2011 to 2020
}

\author{
John R. DOLAN ${ }^{1}$, Jong-Kuk Moon² and Eun Jin YANG² \\ ${ }^{1}$ Laboratoire d'Océanographie de Villefranche-sur-Mer, CNRS and Sorbonne Université UMR 7093, Station Zoologique, \\ Villefranche-sur-Mer 06230, France; dolan@obs-vlfr.fr \\ ${ }^{2}$ Division of Polar Ocean Environment, Korea Polar Research Institute, 26, Songdomirae-ro, Yeonsu-gu, Incheon, 21990, Republic \\ of Korea; jkmoon@kopri.re.kr; ejyang@kopri.re.kr
}

\begin{abstract}
Here we summarize the results from 10 cruises in the Chukchi Sea, in August, each year from 2011 to 2020. Samples for the qualitative analysis of the microzooplankton were obtained from stations located across the Chukchi Sea using a $20 \mu \mathrm{m}$ plankton net. Conditions encountered, in terms of sea ice coverage and chlorophyll concentrations, varied widely from year to year without any obvious relationship with the composition of the microzooplankton assemblage. Examining a total of 242 samples gathered, we found a total of 44 tintinnid species (morphologically distinct forms). Plotting cumulative number of tintinnid species encountered vs cumulative number of samplings gave a typical species accumulation curve showing no sign of saturation suggesting that continued sampling in the Chukchi Sea will likely yield increases in the tintinnid species catalogue. The tintinnid species found ranged widely in lorica opening diameters (LOD) from about $11 \mu \mathrm{m}$ to $80 \mu \mathrm{m}$ in diameter. However, the median size of the LOD of the tintinnid assemblages varied little from year to year ranging only from about $30 \mu \mathrm{m}$ to $40 \mu \mathrm{m}$. Most of the forms encountered were found in samples from only 1 or 2 cruises. Very few forms were found every year throughout the 10 years of sampling. These were 5 species of tintinnids (Acanthostomella norvegica, Leprotintinnus pellucidus, Pytchocylis obtusa, Salpingella acuminata, Salpingella faurei) and the nasselarian radiolarian Amphimelissa setosa. Examples of the morphological variability observed among individuals of Acanthostomella norvegica and Pytchocylis obtusa within single samples are shown with some individuals easily confused with forms described as other species are shown. To our knowledge, our data are the most extensive data set on Chukchi Sea microplankton. We provide all of the data recorded, which may serve as a baseline from which to assess changes projected in Arctic Sea systems, in a supplementary data file.
\end{abstract}

Keywords: Microzooplankton, plankton, tintinnida, radiolaria, polar seas.

\section{INTRODUCTION}

Address for correspondence: John R. Dolan, Laboratoire d'Océanographie de Villefranche-sur-Mer, CNRS and Sorbonne Université UMR 7093, Station Zoologique, Villefranche-sur-Mer 06230, France; dolan@obs-vlfr.fr
It is commonly recognized that Arctic ecosystems are undergoing rapid change due to global warming. Among the Arctic Seas, the Chukchi Sea has seen major changes. The warming of Chukchi Sea waters has 
tripled in rate in the last two decades compared to the long-term trend (Danielson et al. 2020). In recent years, the extent of open water (ice-free) in the Chukchi has reached unprecedented levels (Baker et al. 2020). Consequently, considerable attention has been focused on possible changes in the plankton community, the base of the marine food web. However, at present it is far from clear what the effects of warming will be on the plankton community in the Chukchi Sea, especially with regard to the microzooplankton. The microzooplankton are the trophic link between the phytoplankton and the metazoan zooplankton. Field studies have shown the microzooplankton in the Chukchi, as in other seas, are the major grazers on phytoplankton, consuming most of the primary production (e.g., Yang et al. 2015; Connell et al. 2018). At present, there are considerable uncertainties in predicting the effects of warming on both the prey of microzooplankton, the phytoplankton, and the predators of microzooplankton, the metazoan zooplankton.

With regard to the phytoplankton, models of primary production suggest that declines in sea ice in the Chukchi Sea will lead to increases in primary production (Arrigo and van Dijken 2015) or contrarily, declines in sea ice will result in nutrient depletion, lower phytoplankton biomass, and smaller average cell size of the phytoplankton (Neeley et al. 2018). In support of the latter model scenario, field studies conducted during the summer have found that phytoplankton in a low sea ice year was dominated by small flagellates rather than by diatoms during a year when sea ice is widely present (Lee et al. 2019). With regard to the zooplankton, warming waters in Chukchi Sea has been linked to declines in the abundance and range of some typical species such as the large copepod Calanus glacialis (Spear et al. 2010; Abe et al. 2020), increases in others such as the chaetognath Parasagitta elegans which feeds on copepods (Amano 2019), and range extension northward of some small copepod species (Matsuno 2014).

In our studies of the microzooplankton, we have focused on the tintinnid ciliates and the radiolaria as species identifications are, compared to other taxa of the microzooplankton, relatively easy and they can be sampled using a plankton net allowing sampling large volumes of water. In previous study (Dolan et al. 2014) we compared the microzooplankton communities during the summer with near normal (for the past decade) sea ice extent (i.e., 2011) and in a year of record low sea ice extent (i.e., 2012) in Chukchi Sea. We found tintinnids and radiolarians in much lower abundances in the low sea ice year compared to the year of near normal sea ice despite the higher chlorophyll concentrations found in low sea ice year. Sampling was continued in subsequent years but was qualitative only as no flow meters were used on the plankton net tows used to sample. We have found very considerable inter-annual variability in the composition and distributions of the tintinnids and radiolarians encountered. Here we summarize our findings from 10 years of summer sampling spanning a wide variety of conditions in terms of sea ice extent (Fig. 1) and chlorophyll concentrations. Because species not previously recorded were regularly found, we demonstrate the difficulty of establishing baseline knowledge, as fundamental as a list of species, for the marine microzooplankton in a changing Arctic.

\section{MATERIALS AND METHODS}

Data and samples were collected in the Chukchi Sea from onboard the Korean Research Icebreaker Araon in August each year from 2011 to 2020 Station locations are shown in Fig. 2, exact locations and dates are given in the supplementary data file. Samples for chlorophyll determinations at discrete depths (4-8 depths per station, depending on water column depth) were obtained using a Niskin bottle rosette. Plankton net tows were used to sample the microplankton community.

For chlorophyll $a$ determinations, water samples of $0.3-11$ were filtered through a $0.7 \mu \mathrm{m}$ Whatman glass fiber filter (GF/F). Chlorophyll $a$ concentrations were determined onboard using a Turner Designs Trilogy model fluorometer calibrated using commercial chlorophyll $a$ standards. For details of the protocols see Lee et al. (2007). Net tows were made with a $20-\mu \mathrm{m}$ plankton net of $0.45 \mathrm{~m}$ diameter towed from $100 \mathrm{~m}$ depth to the surface, except in shallow water stations. Net tow material was fixed by standard methods ( $6 \%$ Bouin's or $2 \%$ Lugol's, final concentration). Aliquots $(0.1-3 \mathrm{ml})$ were examined in settling chambers using an inverted microscope equipped with DIC optics. Multiple aliquots were examined until a net material sample volume representing material from at least 10-20 1 (putative volume sampled assuming no net clogging) was analyzed. Tintinnid species identifications were made based on lorica morphology using the monographs of Kofoid and Campbell (1929, 1939), Hada (1937), and Zhang et al. (2012). Each tintinnid species was assigned the average dimensions reported in Kofoid and Campbell $(1929,1939)$ and Hada (1937). Tintinnid species were grouped in size class categories of lorica opening diameter (LOD), binned over $4 \mu \mathrm{m}$ intervals beginning with the overall smallest diameter $(11 \mu \mathrm{m})$ and continuing to the largest diameter encountered. Radiolarians were overwhelming dominated by a single morphotype identified by Noritoshi Suzuki (Tohoku University) as Amphimelissa setosa.

Difficulties in distinguishing species of the arctic tintinnids Acanthostomella and Ptychocylis due to apparent morphological variability is relatively well-documented (i.e. Davis 1981; 1985) but notably variability has been shown among mostly empty lorica 


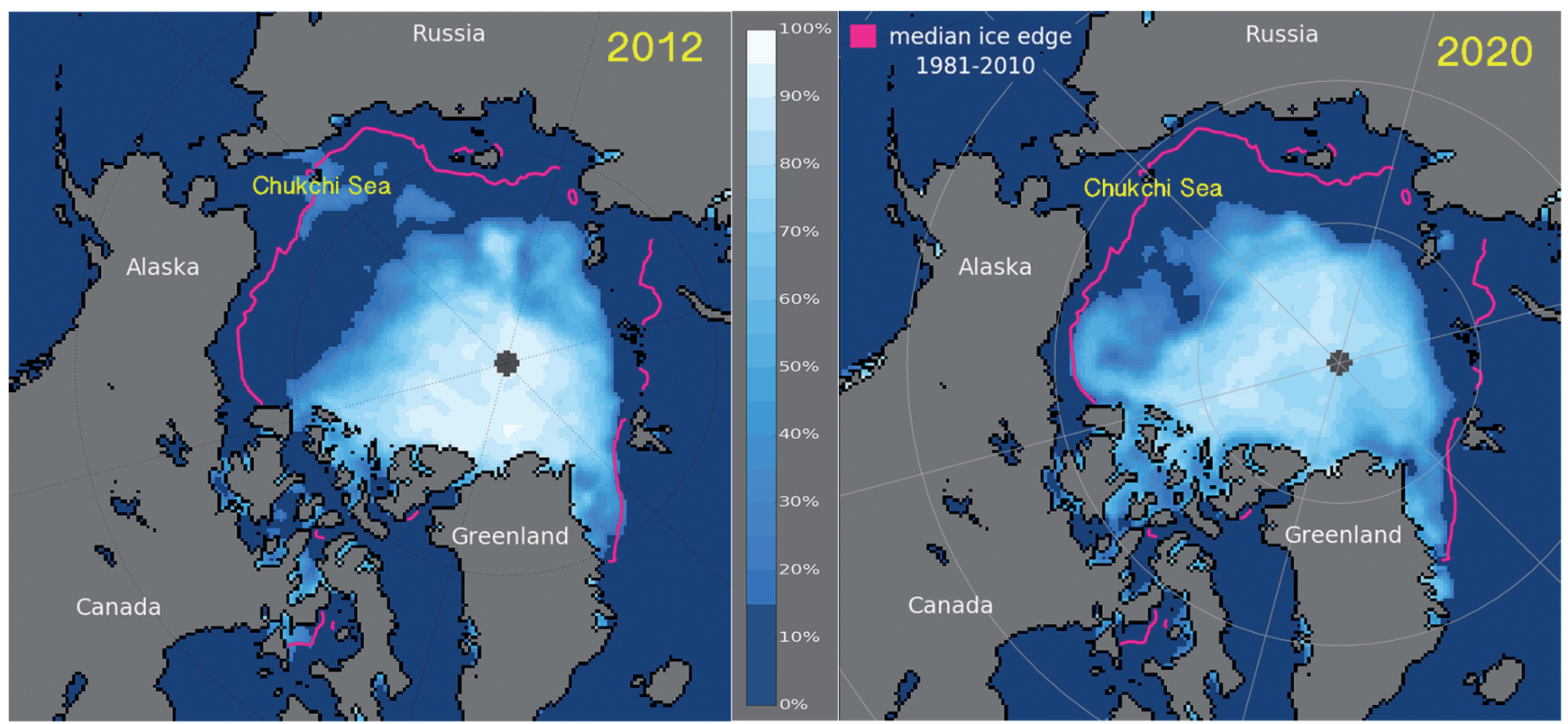

Fig. 1. Examples of the distinct sea ice conditions in August encountered through the 10 cruises. Color-coding indicates areas of sea ice coverage varying from $100 \%$ to $0 \%$, or open water. The year 2012 was a record year of low sea ice extent while 2020 was year of sea ice extent more common in recent years.

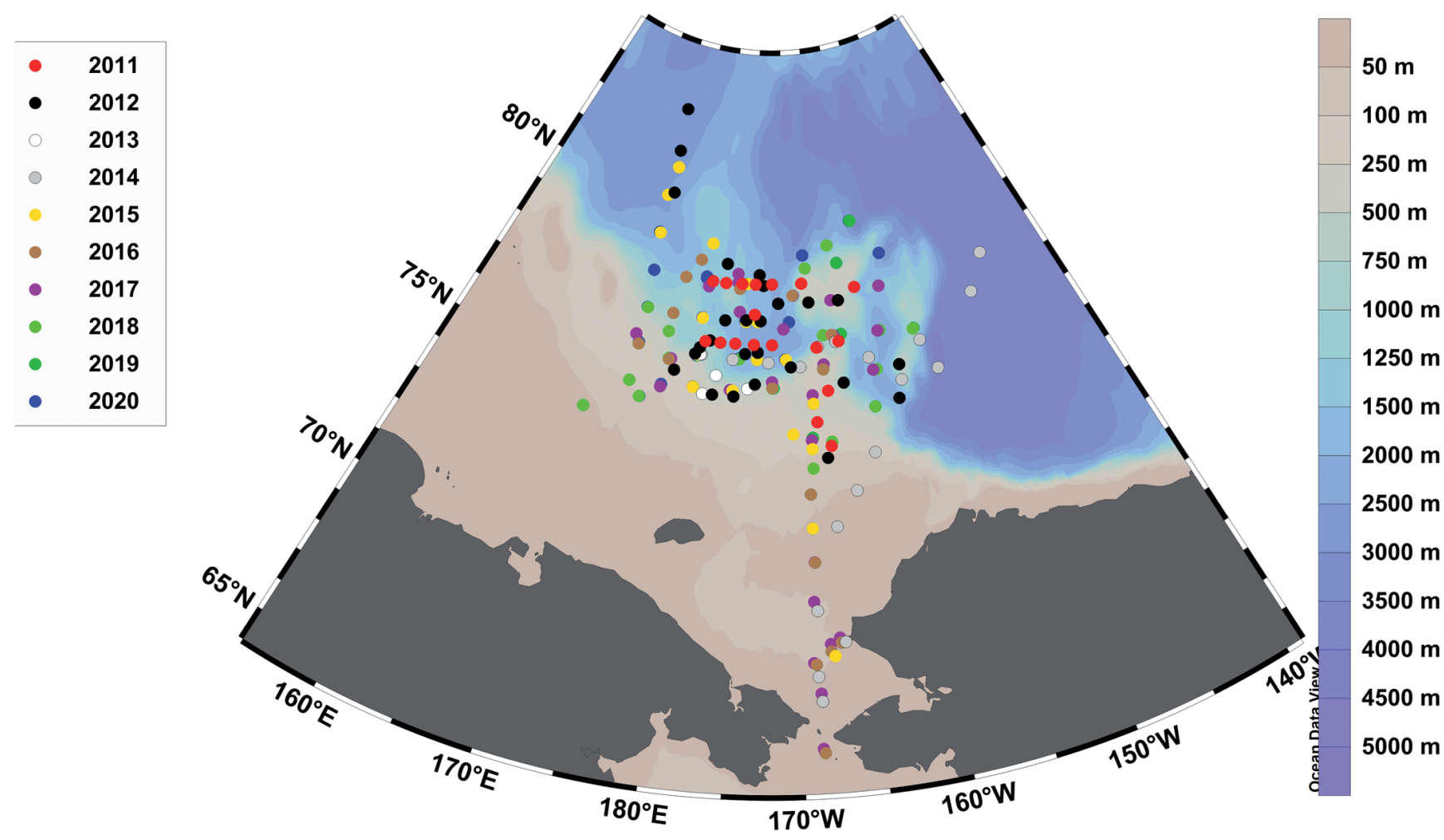

Fig. 2. Sampling locations, 2011-2020 in Chukchi Sea. See supplementary file for details of station locations and sampling dates. Colored zones indicate water column depth. 
chosen from multiple samplings from different locations at different times. We attempted an assessment of morphological variability likely to be commonly encountered by examining cells from a single sample. We chose a sample with a relatively high abundances of Ptychocyliss and another with a high abundances of Acanthostomella. For each we imaged the first 18, properly orientated, loricas containing cells, encountered in several highly diluted aliquots from the sample. The number 18 was chosen as a practical limit to the number cells imaged given that it was necessary to examine several highly diluted samples so cells would be free of extraneous matter and frequently loricas containing cells were not well-oriented.

\section{RESULTS}

Table 1 summarizes the cruise data, the characteristics of the environments and the characteristics of the tintinnid assemblages encountered. Briefly, the extent of sea ice in August throughout the entire Arctic Ocean varied through the 10 years of sampling. The extent of ice-free water in spring, a metric of pre-summer conditions in the Chukchi Sea (see Table 1: 'May Open Water') in Chukchi Sea varied as well. Comparing years, the average chlorophyll concentration found in the stations sampled in a given year varied by an order of magnitude (0.19-1.95 $\mu \mathrm{g} 1-1)$. Variability in chlorophyll concentrations among stations within a given year was very high every year with coefficients of variation of $79-140 \%$. Comparing years, the number of tintinnid species encountered ranged from 6 to 24 and was unrelated to the number of stations sampled, the latitudinal extent sampled, or the average chlorophyll concentration of the stations sampled.

However, the morphological characteristics of the pool tintinnid species encountered each year, as a whole, were relatively consistent. Each year the range of lorica opening diameters (LOD) of the species covered a wide range, from about $11 \mu \mathrm{m}$ to $80 \mu \mathrm{m}$ and the modal LOD (i.e, the most common) of the species found from year to year varied little, ranging from $29 \mu \mathrm{m}$ to $41 \mu \mathrm{m}$.

Generally, each year's samples contained tintinnid species not previously encountered. A total of 44 putative species were found (Table 2). Three forms could not be reliably associated with known species: a small tubular Eutintinnus, about $50 \mu \mathrm{m}$ long and $13 \mu \mathrm{m}$ in diameter noted as Eutintinnus sp. LOD13 and two Tintinnidium spp, both of variable lengths. One form was about $25 \mu \mathrm{m}$ in diameter, noted as Tintinnidium sp A and another about $50 \mu \mathrm{m}$ in diameter noted as Tintinnidium sp B. Plotting cumulative number of samples examined vs. cumulative number of species encountered, yielded a classic species accumulation curve with no sign of a plateau (Fig. 3). Most of the species were found only in 1 or 2 years of the 10 years of sampling (Fig. 3). These species were also not widely distributed, found only in 1 or 2 stations (Table 2 ). Only a few forms were consistently found across all the years of sampling. These were 4 species of tintinnids (Acanthostomella norvegica, Leprotintinnus pellucidus, Ptychocylis obtusa, Salpingella faurei) and the nasselarian radiolarian Amphimelissa setosa. We encountered

Table 1. Summary of the 2011-2020 sampling, conditions, and tintinnid assemblages. August Sea Ice Extent: for the entire Arctic Ocean, $\left(106 \mathrm{~km}^{2}\right)$, from the National Snow and Ice Data Center; May Open Water: Annual extent of open water in the Chukchi Sea on May $15^{\text {th }}$, $\left(103 \mathrm{~km}^{2}\right)$, from Baker et al. (2020). Coefficient of variation of the concentration of chlorophyll among station is indicated by CoV [Chl]. Modal LOD SC indicates the value of the modal size-class of lorica opening diameter of the tintinnid species found.

\begin{tabular}{llllllllll}
\hline Year & Cruise ID & Dates & $\begin{array}{l}\text { August Sea } \\
\text { Ice Extent }\end{array}$ & $\begin{array}{l}\text { May } \\
\text { Open } \\
\text { Water }\end{array}$ & \# Stations & Avg [Chl] $\mu g 1^{-1}$ & $\begin{array}{l}\text { CoV } \\
{[\text { Chl] }}\end{array}$ & \# Tintinnid spp & Modal LOD SC $(\mu \mathrm{m})$ \\
\hline 2011 & ARA02 & $08 / 2-08 / 16$ & 3.4 & 50 & 18 & 0.19 & 140 & 9 & $35-38$ \\
2012 & ARA03 & $08 / 3-08 / 16$ & 2.9 & 15 & 24 & 0.42 & 104 & 9 & $39-42$ \\
2013 & ARA04 & $08 / 13-08 / 16$ & 4.2 & 22 & 11 & 0.20 & 79 & 6 & $39-42$ \\
2014 & ARA05 & $08 / 1-08 / 19$ & 4.4 & 95 & 19 & 1.93 & 109 & 21 & $35-38$ \\
2015 & ARA06 & $08 / 3-08 / 20$ & 3.6 & 65 & 22 & 1.18 & 124 & 12 & $31-34$ \\
2016 & ARA07 & $08 / 5-08 / 20$ & 3.3 & 75 & 23 & 0.74 & 124 & 14 & $28-30$ \\
2017 & ARA08 & $08 / 6-08 / 23$ & 3.6 & 140 & 25 & 0.82 & 109 & 19 & $35-38$ \\
2018 & ARA09 & $08 / 4-08 / 24$ & 3.9 & 145 & 26 & 1.00 & 121 & 10 & $35-38$ \\
2019 & ARA10 & $08 / 5-08 / 26$ & 3.2 & 165 & 27 & 1.95 & 138 & 24 & $35-38$ \\
2020 & ARA11 & $08 / 4-08 / 31$ & 3.1 & ND & 43 & 0.85 & 132 & 21 & $31-34$ \\
\hline
\end{tabular}


Table 2. Tintinnid species found and their frequencies of occurrence 2011-2020 along with the radiolarian Amphimelissa setosa. Species denoted '^' were not previously reported from the Chukchi Sea in the Dolan et al. 2017 review of Arctic tintinnid records. Species in red are 'oncers', found only once in 1 station. Species de-noted '*' and 'o' are suspected 'polymorphs', morphological varieties of a single species of Parafavella* (Jung et al. 2018) or Salpingella ${ }^{\circ}$ (Dolan and Yang 2017).

\begin{tabular}{|c|c|c|}
\hline Species & \# Years Found & Avg \% Stations Occurrence per Year in Year(s) Found \\
\hline Acanthostomella norvegica & 10 & 31.2 \\
\hline Amphimelissa setosa & 10 & 67.7 \\
\hline Bursaopsis vitrea & 2 & 0.8 \\
\hline Codonellopsis frigida & 3 & 4.5 \\
\hline Codonellopsis pusilla^ & 2 & 1.5 \\
\hline Eutintinnus apertus & 1 & 0.6 \\
\hline Eutintinnus sp $13 L^{L} D^{\wedge}$ & 3 & 3.1 \\
\hline Eutintinnus tubulosus ${ }^{\wedge}$ & 1 & 0.2 \\
\hline Eutintinnus turris ${ }^{\wedge}$ & 1 & 0.4 \\
\hline Helicostomella subulata & 5 & 3.0 \\
\hline Leprotintinnus pellucidus & 10 & 18.6 \\
\hline Metacylis vitreoides & 2 & 1.7 \\
\hline Parafavella denticulata* & 2 & 1.1 \\
\hline Parafavella gigantea* & 2 & 0.8 \\
\hline Parafavella parumdentata* & 7 & 7.2 \\
\hline Parafavella subrotundata* & 1 & 0.5 \\
\hline Ptychocylis obtusa & 10 & 83.0 \\
\hline Salpingacantha $s p^{\circ}$ & 2 & 10.7 \\
\hline Salpingella acuminata ${ }^{\circ}$ & 9 & 37.5 \\
\hline Salpingella faurei & 10 & 38.8 \\
\hline Stenosomella nivalis & 2 & 0.6 \\
\hline Stenosomella ventricosa & 3 & 4.4 \\
\hline Tintinidium sp A & 1 & 0.5 \\
\hline Tintinnidium $s p$ B & 1 & 0.5 \\
\hline Tintinnopsis frimbriata & 2 & 2.3 \\
\hline Tintinnopsis acuminata & 5 & 7.6 \\
\hline Tintinnopsis baltica & 2 & 0.9 \\
\hline Tintinnopsis beroidea & 6 & 5.7 \\
\hline Tintinnopsis cylindrica ${ }^{\wedge}$ & 2 & 1.4 \\
\hline Tintinnopsis karajacensis & 2 & 1.8 \\
\hline Tintinnopsis lata & 6 & 6.7 \\
\hline Tintinnopsis levigata ${ }^{\wedge}$ & 1 & 0.4 \\
\hline Tintinnopsis major & 1 & 1.2 \\
\hline Tintinnopsis meunieri & 1 & 0.7 \\
\hline Tintinnopsis minuta/nana & 3 & 1.5 \\
\hline Tintinnopsis nitida & 1 & 0.5 \\
\hline Tintinnopsis radix & 2 & 0.7 \\
\hline Tintinnopsis rapa & 8 & 18.5 \\
\hline Tintinnopsis sinuata & 1 & 0.4 \\
\hline Tintinnopsis strigosa & 1 & 0.4 \\
\hline Tintinnopsis subacuta & 2 & 1.2 \\
\hline Tintinnopsis tubulosoides $^{\wedge}$ & 1 & 0.7 \\
\hline Tintinnopsis turbo & 4 & 4.8 \\
\hline Tintinnopsis urnula & 3 & 2.6 \\
\hline Tintinnopsis vasculum ${ }^{\wedge}$ & 1 & 1.9 \\
\hline
\end{tabular}



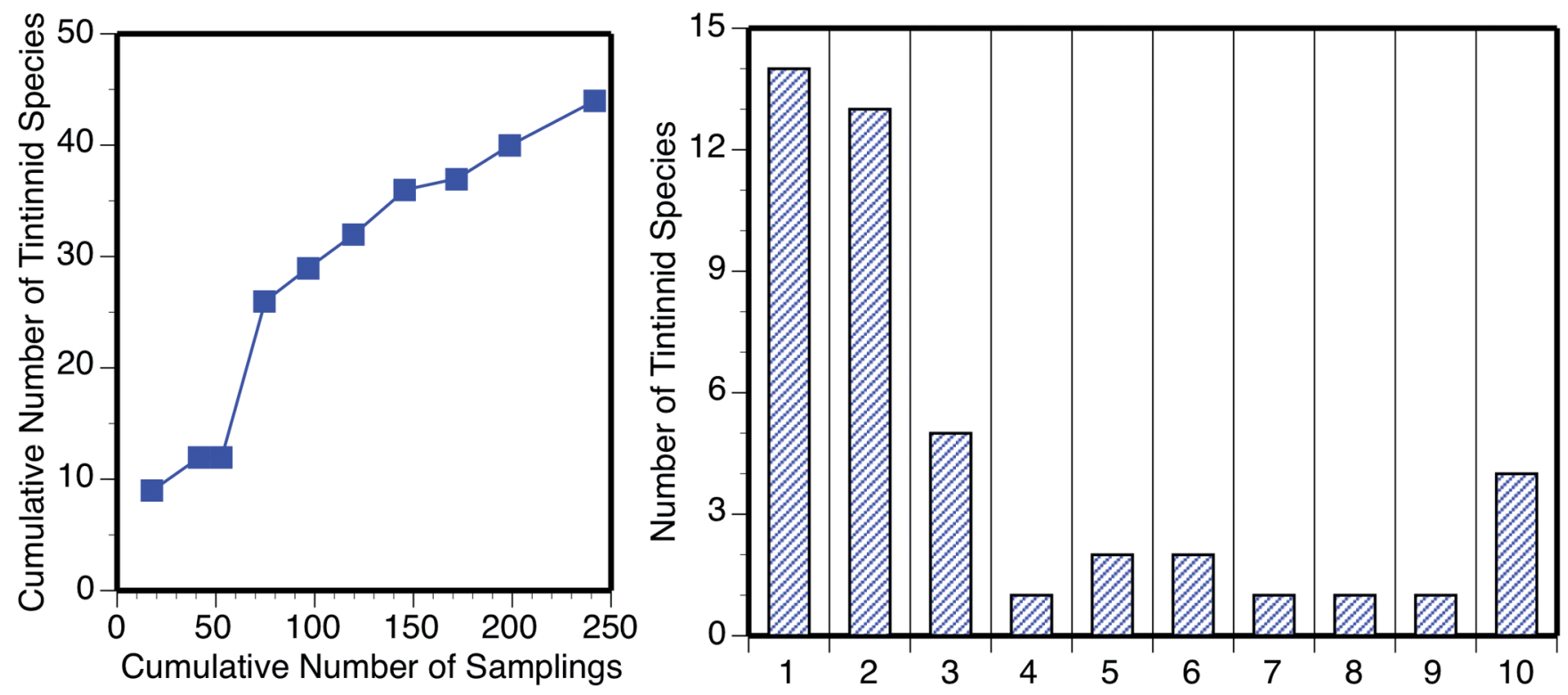

Fig. 3. The left panel shows a species accumulation curve: the cumulative number of forms encountered as a function of sampling effort, here shown as the number of samples or stations sampled over the 10-year period of our study. Right panel shows the temporal distributions: how many species of tintinnids were found in all 10 years, 9 years, etc. Note that the majority of species were found in samples from only 1 or 2 years.

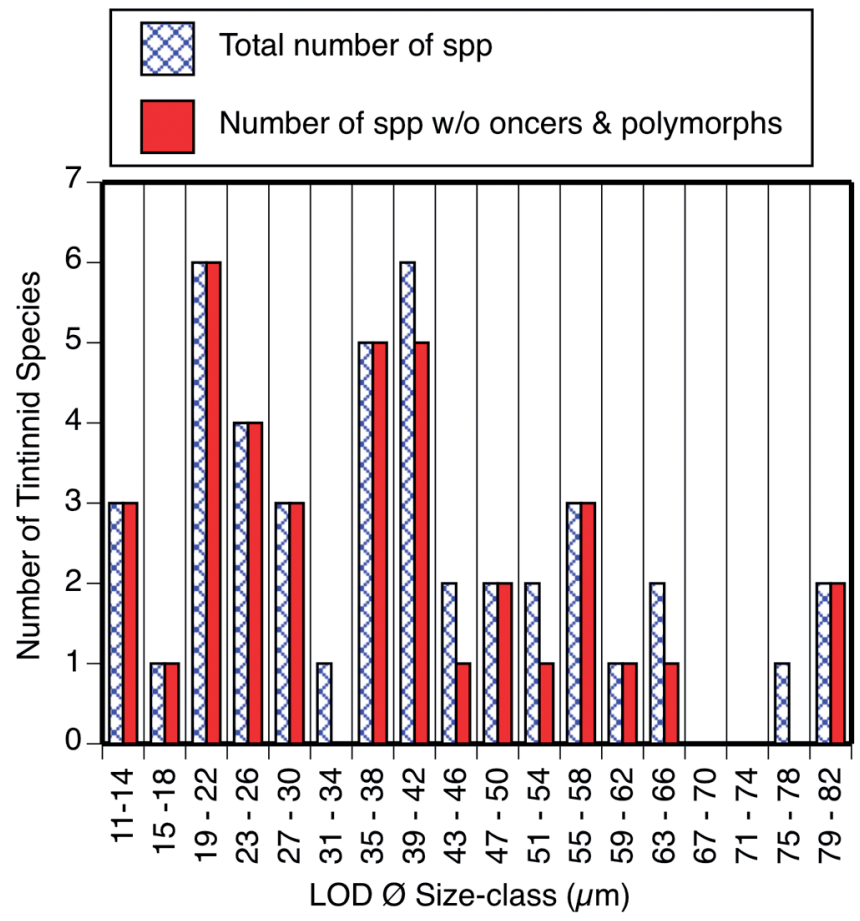

Fig. 4. The distribution of lorica oral diameters (LOD) of the tintinnid species found over 10 years of sampling. The LOD of a species is related positively to the diameter of the preferred prey size, about $25 \%$ of the LOD. Note that the most common LODs are 19-30 $\mu \mathrm{m}$ and 35-42 $\mu \mathrm{m}$, suggesting most species feed on small prey $(5-10 \mu \mathrm{m}$ diameter). Note also that excluding species found only once and species suspected to be morphological variants of another species (see Table 2) yields few changes in the distribution. some tintinnid morphotypes suspected to be varieties of a single species and these are denoted in the Table 2.

The morphological attributes of the tintinnid species found, in terms of the lorica opening diameters (LOD) of the species is shown in Fig. 4. The LOD of a species is related positively to the diameter of the preferred prey size, about $25 \%$ of the LOD (Dolan 2011). A wide range of LODs characterize the species pool found. The most common LODs were 19-30 $\mu \mathrm{m}$ and 35-42 $\mu \mathrm{m}$, either including all forms encountered, or excluding those found only once at one station 'oncers', and forms suspected of being alternative forms of another species 'polymorphs'. Thus, most species likely feed on small prey $(5-10 \mu \mathrm{m}$ diameter).

We found considerable morphological variablity among individuals of the forms we identified as Acanthostomella norvegica and Pytchocylis obtusa. The morphological variability of Acanthostomella norvegi$c a$ found in a single sample is shown in Fig. 5. Two of the 18 individuals imaged have lorica morphologies resembling those of a co-gener $A$. gracilis. The morphological variability of Ptychocylis obtusa found in a single sample is shown in Fig. 6. Of the 18 individuals imaged, 3 have loricas resembling those of forms recognized as different species of Pytchocylis: P. drygalski and P. acuta. 


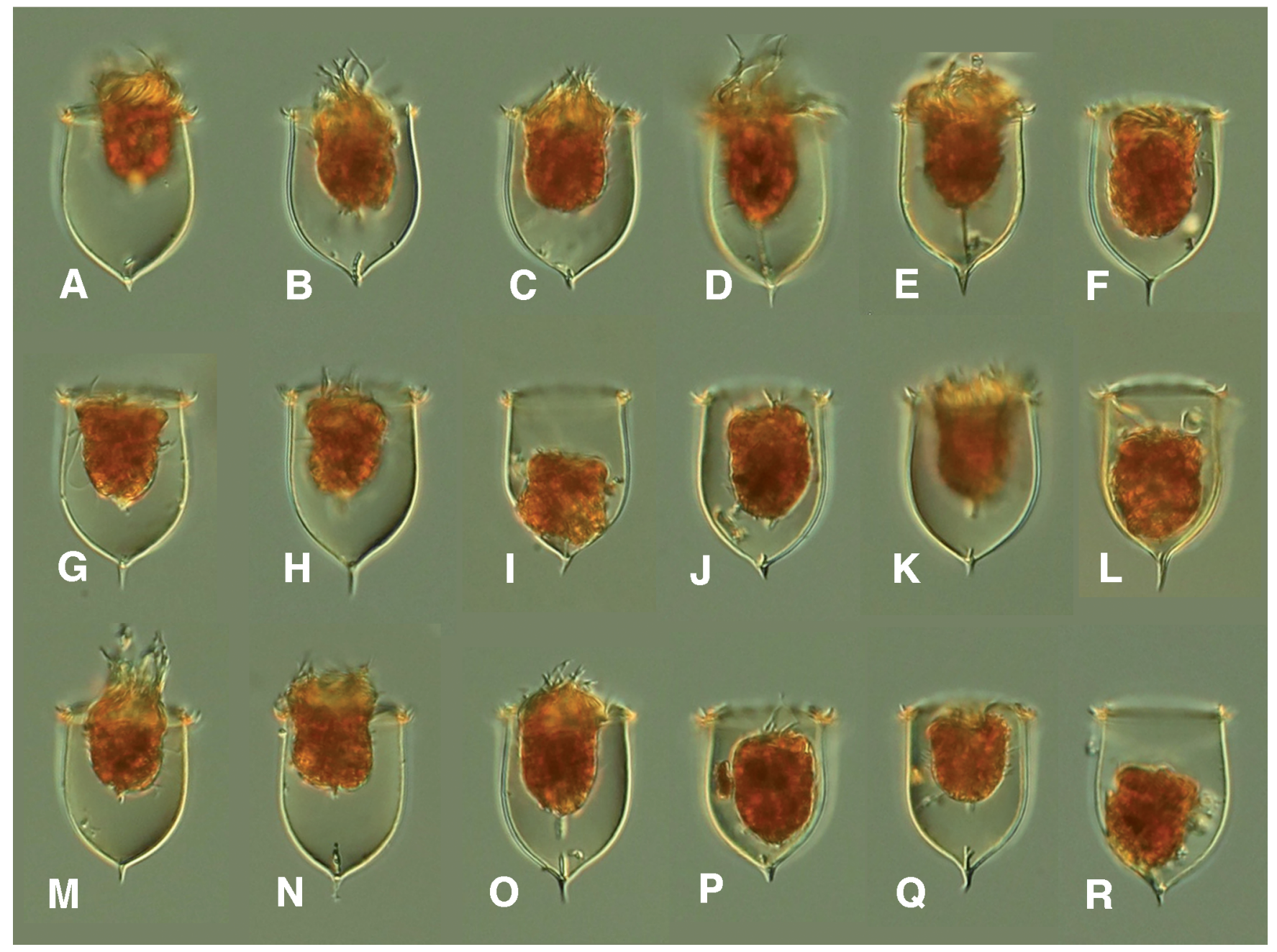

Fig. 5. Morphological variability of Acanthostomella norvegica found in a single sample. The 18 cells shown were the first properly orientated cells encountered in sample aliquots from Station 17 of the 2017 cruise. Certain individuals shown (e.g., A and K) have lorica morphologies resembling those of a co-gener $A$. gracilis, first described as a variety of $A$. norvegica as they differ only in the near absence of an aboral horn. As shown here, the aboral point or horn appears to be quite variable.

\section{DISCUSSION}

Excluding forms not assigned to distinct species (i.e., 'Genus $X s p$ '.), we found 41 species of tintinnids. Our multi-year sampling uncovered many more tintinnid species than those reporting on recent single year studies, even those that gathered samples from a large number of stations in the Chukchi Sea. Li et al. (2016) found 17 species in 2016 samples from 20 Chukchi Sea stations; Matsuno et al. (2014) found 14 species in samples from 59 stations sampled in 2010; Xu et al. (2018) reported 9 species in samples gathered from 31 stations in 2016 while Wang et al. (2019) found only 7 species in material from 27 Chukchi Sea stations in 2016. These 4 studies involved material gathered from a total of 137 stations in 3 years and found, all told, 38 species. They all employed examining material from small volumes of water $(0.025-1.01)$ compared to our examination of material from 10's of liters. Nonetheless, the pooled sampling effort of 137 stations recovering 38 species is comparable to the figure of 32 species we found after sampling 146 stations over 7 years. However, the species list derived from each of the 4 studies differs considerably from the others without a single species found in all 4 of the studies. Furthermore, pooling the lists of the 4 studies yields a set of species quite different from ours of the first 146 samplings, covering the years 
Table 3. Comparison of tintinnid species lists from four recent studies in the Chukchi Sea representing a total of 137 stations sampled and our results from the first 7 years of sampling (2011-2017) representing a comparable sampling effort of 146 stations sampled. Species shown in red are unique to the list while those shown black are common to the two lists. The superscript 'A' identifies species reported in Matsuno et al. 2014, 'B' those reported by Li et al. (2016), 'C' species reported by Xu et al. (2018), and 'D' species reported by Wang et al. (2019).

\begin{tabular}{|c|c|}
\hline $\begin{array}{l}\text { Species from Matsuno et al. } 2014^{\mathrm{A}} \text {, Li et al. } 2016^{\mathrm{B}} \text {, Xu et al. } 2018^{\mathrm{C}} \text {, } \\
\text { Wang et al. } 2019^{\mathrm{D}}\end{array}$ & Species 2011-2017 \\
\hline Acanthostomella conicoides ${ }^{A}$ & Acanthostomella norvegica \\
\hline Acanthostomella norvegica $a^{A, B, D}$ & Bursaopsis vitrea \\
\hline Canthariella pyramidata $^{A}$ & Codonellopsis frigida \\
\hline Codonellopsis frigida $a^{A, B}$ & Codonellopsis pusilla \\
\hline Codonellopsis morchella ${ }^{A}$ & Eutintinnus apertus \\
\hline Codonellopsis schabi ${ }^{A}$ & Eutintinnus turris \\
\hline Eutintinnus apertus ${ }^{C}$ & Helicostomella subulata \\
\hline Eutintinnus pectinis $^{D}$ & Leprotintinnus pellucidus \\
\hline Favella azorica $^{A}$ & Metacylis vitriodes \\
\hline Favella ehrenbergi ${ }^{C}$ & Parafavella giganta \\
\hline Helicostomella subulata ${ }^{B}$ & Parafavella parumdentata \\
\hline Leprotintinnus pellucidus ${ }^{B}$ & Parafavella subrotundata \\
\hline Ormosella trachelium ${ }^{A}$ & Ptychocylis obtusa \\
\hline Parafavella elegans ${ }^{B, D}$ & Salpingella acuminata \\
\hline Parafavella faceta ${ }^{B}$ & Salpingella faurei \\
\hline Parafavella jorgenseni ${ }^{A, B}$ & Stenosomella ventricosa \\
\hline Parafavella promissa ${ }^{B}$ & Tintinnopsis frimbriata \\
\hline Parafavella ventricosa ${ }^{B}$ & Tintinnopsis acuminata \\
\hline Ptychocylis acuta ${ }^{B, D}$ & Tintinnopsis baltica \\
\hline Ptychocylis obtusa ${ }^{A}$ & Tintinnopsis beroidea \\
\hline Ptychocylis urnula ${ }^{D}$ & Tintinnopsis cylindrica \\
\hline Salpingacantha perca ${ }^{A}$ & Tintinnopsis karajacensis \\
\hline Salpingella acuminata ${ }^{D}$ & Tintinnopsis lata \\
\hline Salpingella faurei ${ }^{D}$ & Tintinnopsis major \\
\hline Stenosemella nivalis ${ }^{A, B, C}$ & Tintinnopsis minuta/nana \\
\hline Stenosemella ventricosa ${ }^{A}$ & Tintinnopsis radix \\
\hline Stenosomella pacifica ${ }^{C}$ & Tintinnopsis rapa \\
\hline Tintinnidium mucicola ${ }^{A}$ & Tintinnopsis sinuata \\
\hline Tintinnopsis acuminata $^{B}$ & Tintinnopsis strigosa \\
\hline Tintinnopsis baltica ${ }^{B, C}$ & Tintinnopsis subacuta \\
\hline Tintinnopsis japonica ${ }^{B}$ & Tintinnopsis turbo \\
\hline Tintinnopsis kofoidi ${ }^{B}$ & Tintinnopsis urnula \\
\hline \multicolumn{2}{|l|}{ Tintinnopsis mayer $^{B}$} \\
\hline \multicolumn{2}{|l|}{ Tintinnopsis minuta ${ }^{C}$} \\
\hline \multicolumn{2}{|l|}{ Tintinnopsis nana ${ }^{C}$} \\
\hline Tintinnopsis rapa ${ }^{B}$ & \\
\hline Tintinnopsis tubulosoides ${ }^{C}$ & \\
\hline
\end{tabular}


2011-2017, with only 15 species common to both lists (Table 3). This underline the fact that most of the species recorded from the Chukchi Sea have been found in only a few instances and it is likely that continued sampling will uncover more species not previously found (e.g. Fig. 3).

In our review of Arctic Ocean records (Dolan et al. 2017), based on publications published up to 2016, we found that out of the 89 species recorded from the Arctic Ocean, 47 were known from Chukchi Sea records. We concluded that further sampling in Arctic Seas would likely increase the number of species known to occur. Revising the Chukchi Sea list to account for the species records given in $\mathrm{Xu}$ et al. 2017, Wang et al. 2019, and the data presented here, yields a list of 60 Chukchi Sea tintinnid species. A plot of the temporal growth of the Chukchi Sea tintinnid species list is shown in Fig. 7. Among the new species records for the Chukchi are several appear that to be new records for the Arctic Ocean: Eutintinnus pectinus, E. turris, Stenosomella pacifica, Tintinnopsis cylindrica, T. levigata, and $T$. strigosa. Thus, there are now 95 species known to have been found in the Arctic Ocean and of those 95 species, 60 have been found in Chukchi Sea.

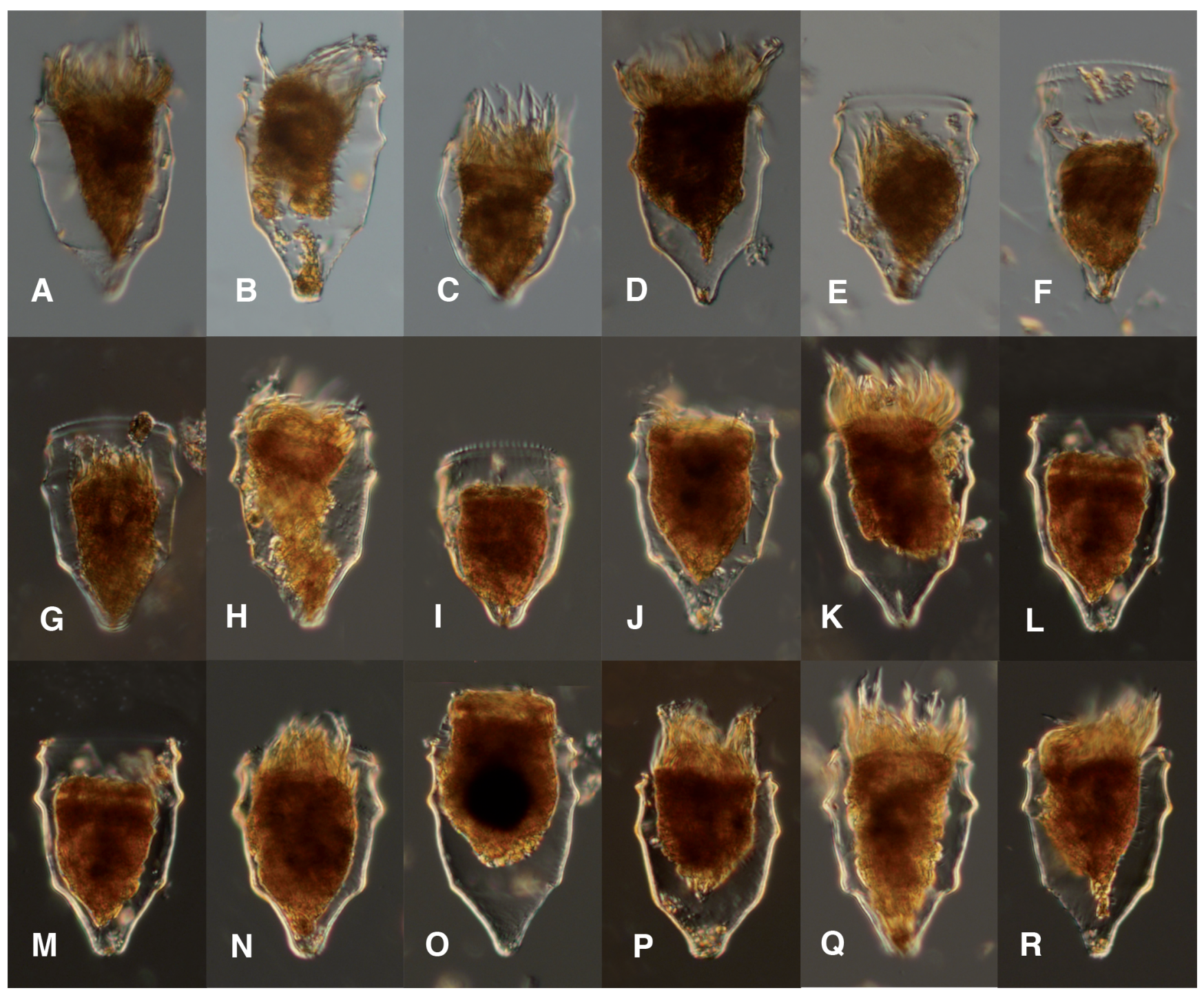

Fig. 6. Morphological variability of Ptychocylis obtusa found in a single sample. The 18 cells shown were the first properly orientated cells encountered in a sample aliquots from Station 9 of the 2014 cruise. Certain individuals shown have lorica morphologies resembling those of forms recognized as distinct species of Ptychocylis: P. drygalski (C) and P. acuta (F and $\mathrm{O})$. 


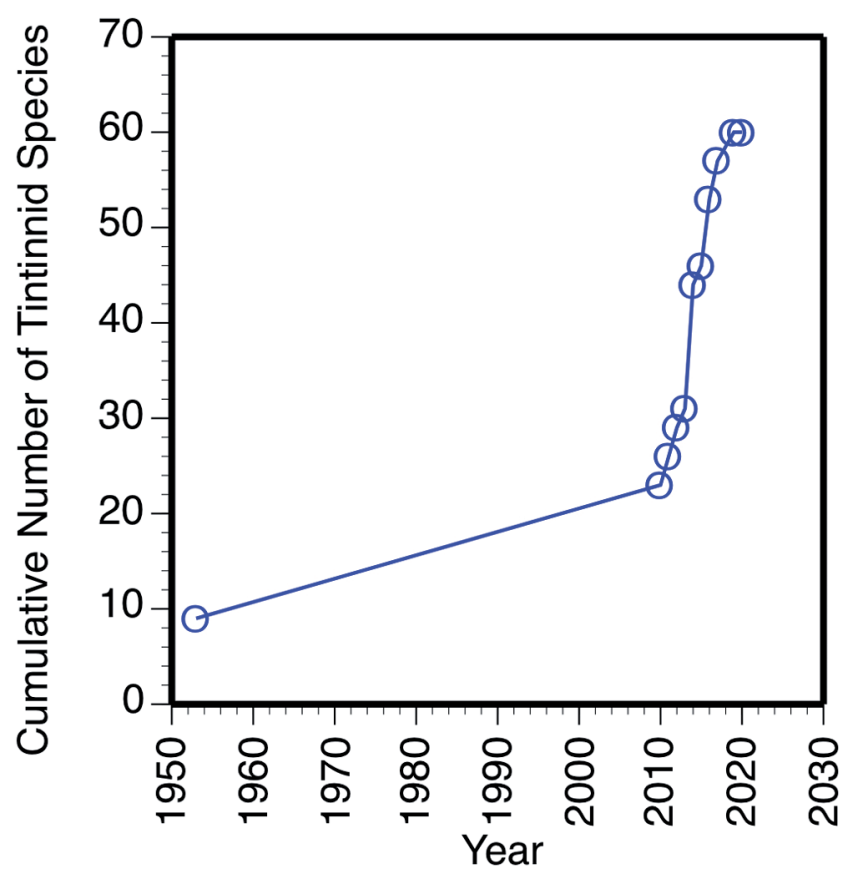

Fig. 7. The growth in the list of tintinnid species reported from the Chukchi Sea beginning with the first sampling in 1953 up to and including our 2020 sampling.

The list of the 60 species now known for Chukchi Sea, with sampling year first found for each species, and the reference, is given in the supplementary file. Data are from Bursa 1963, Matsuno et al. 2014, Li et al. 2016, Yokoi et al. 2016, Dolan et al. 2017, Xu et al. 2018, Wang et al. 2019, and this study.

One might postulate that many apparently new species records are 'mistaken'. This is because many of the species recorded are likely to be morphological variants of another species or are synonyms. Polymorphism has been demonstrated in Parafavella based on genetic markers (Jung et al. 2017). Polymorphism is strongly suspected to characterise Acanthostomella (Davis 1985) and as shown in Fig. 5, in Ptychocylis (Davis 1981) and as shown in Fig. 6., as well as in Salpingacantha (Dolan and Yang 2017). Tintinnopsis species listed include forms thought to be synonyms, for example $T$. $c y$ lindrica and T. kofoidi (Agatha and Reidel-Lorjé 2006). However, there is no reason to believe that 'mistaken' new records have increased disproportionately with time. It is more likely that they represent a consistent fraction over time. The growth in the number of species found in the Chukchi Sea will likely continue with continued sampling.

\section{CONCLUSION}

Our results from 10 years of sampling, and our analysis of Chukchi Sea records, show that our knowledge of the microzooplankton is far from adequate to allow prediction of the effects of warming. Our knowledge of basic aspects such as which species are found in the Chukchi Sea appears to be incomplete. We did find that a few forms appeared to be 'typical'. Some tintinnid species were consistently found, such as Ptychocylis obtusa and Acanthostomella norvegica as well as the radiolarian Amphimelissa setosa. We also found that in the tintinnid assemblages over the years, the modal lorica opening diameter (LOD) varied in a narrow range, from about 30 to $40 \mu \mathrm{m}$. Looking to the future, changes in the occurrences of the 'typical' forms, or shifts in the modal LOD of the tintinnid assemblages, may be regarded as signs of changes in the microzooplankton, rather than the discovery of previously unrecorded forms.

Acknowledgements. This research is a part of the project titled "Korea-Arctic Ocean Observing System (K-AOOS)", the Korea Polar Research Institute (KOPRI) 2016245, funded by the Ministry of Oceans and Fisheries (MOF). We appreciated the remarks and suggestions of the anonymous reviewers on the first version of this manuscript. Their comments led to significant improvements in the paper.

\section{Supplementary Data File}

In the Excel file "DolanYangMsSuppFile.xlsx" are given complete species lists for each year by station along with a listing of all of the known Chukchi Sea tintinnid species, with year of first record, as well as an image of the undescribed small Eutintinnu species found. The data file is also available for download through Figshare, https://doi.org/10.6084/m9.figshare.15169683.v1

\section{REFERENCES}

Abe Y., Matsuno K., Fujiwara A., Yamaguchi A. (2020) Review of spatial and inter-annual changes in the zooplankton community structure in the western Arctic Ocean during summers of 20082017. Prog. Oceanogr. 186: 102-391

Agatha S. and Reidel-Lorjé J.C. (2006) Redescription of Tintinnopsis cylindrica Daday, 1887 (Ciliophora: Spirotricha) and unification of tintinnid terminology. Acta Protozool., 45: 137-151

Amano K., Abe Y., Matsuno K., Yamaguchi A. (2019) Yearly comparison of the planktonic chaetognath community in the Chukchi Sea in the summers of 1991 and 2007. Pol. Sci. 19: 112-119

Arrigo K. R., van Dijken G. L. (2015) Continued increases in Arctic Ocean primary production. Prog. Oceanogr. 136: 60-70 
Baker M. R., Kivva K. K., Pisareva M. N., Watson J. T., Selivanova J. (2020) Shifts in the physical environment in the Pacific Arctic and implications for ecological timing and conditions. Deep Sea Res. Part II 177: 104-802

Bursa A. (1963) Phytoplankton in coastal waters of the Arctic Ocean at Point Barrow Alaska. Arctic 16: 239-262

Connell P. E., Michel C., Meisterhans G., Arrigo K. R., Caron D. A. (2018) Phytoplankton and bacterial dynamics on the Chukchi Sea Shelf during the spring-summer transition. Mar. Ecol. Prog. Ser. 602: 49-62

Danielson S. L., Ahkinga O., Ashjian C., Basyuk E., Cooper L. W., Eisner L., Farley E., Iken K. B., Grebmeier J. M., Juranek L., Khen G., Jayne S. R., Kikuchi T., Ladd C., Lu K., McCabe R. M., Moore G. W. K., Nishino S., Ozenna F., Pickart R. S., Ployakov I., Stabeno P. J., Thoman R., Williams W. J., Wood K., Weingartner T. J. (2020) Manifestation and consequences of warming and altered heat fluxes over the Bering and Chukchi Sea continental shelves. Deep Sea Res. Part II 177: 104-781

Davis C. C. (1981) Variations of lorica shape in the genus Ptychocylis (Protozoa: Tintinnina) in relation to species identification. J. Plankton Res. 3: 433-443

Davis C. C. (1985) Acanthostomella norvegica (Daday) in Insular Newfoundland waters, Canada (Protozoa: Tintinnina). Int. Rev. Ges. Hydrobiol. 70: 21-26

Dolan J. R. (2010) Morphology and ecology in tintinnid ciliates of the marine plankton: correlates of lorica dimensions. Acta Protozool. 49: 235-244

Dolan J. R., Yang E. J. (2017) Observations of apparent lorica variability in Salpingacantha (Ciliophora: Tintinnida) in the Northern Pacific and Arctic Oceans. Acta Protozool. 56: 217-220

Dolan J. R., Yang E. J., Kim T. W., Kang S. H. (2014) Microzooplankton in a Warming Arctic: A Comparison of Tintinnids and Radiolarians from Summer 2011 and 2012 in the Chukchi Sea. Acta Protozool. 53: 101-113

Dolan J. R., Pierce R. W., Yang E. J. (2017). Tintinnid ciliates of the marine microzooplankton in Arctic Seas: a compilation and analysis of species records. Pol. Biol. 40: 1247-1260

Hada Y. (1937) The fauna of Akkeshi Bay IV. The pelagic ciliata. J. Fac. Sci. Hokkaido Imperial Univ, Series 6, Zool 5: 147-216

Jung J. H., Moon J. H., Park K. M., Kim S., Dolan J. R., Yang E. J. (2018) Novel insights into the genetic diversity of Parafavella based on mitochondrial CO1 sequences. Zool. Scripta, 47: 743-755

Kofoid C. A., Campbell A. S. (1929) A Conspectus of the Marine and Freshwater Ciliata Belonging to the suborder Tintinnoinea, with Descriptions of New Species Principally from the Agassiz Expedition to the Eastern Tropical Pacific 1904-1905. Univ. Calif. Publ. Zool. 34: 1-403

Kofoid C. A., Campbell A. S. (1939) The Ciliata: The Tintinnoinea. Bull. Mus. Comp. Zool. Harvard 84: 1-473

Lee Y., Min J. O., Yang E. J., Cho K. H., Jung J., Park J., Moon J. K., Kang S. H. (2019) Influence of sea ice concentration on phytoplankton community structure in the Chukchi and East
Siberian Seas, Pacific Arctic Ocean. Deep Sea Res. Part I 147: 54-64

Li H., Xu Z., Zhang W., Wang S., Zhang G., Xiao T. (2016) Boreal tintinnid assemblage in the Northwest Pacific and its connection with the Japan Sea in summer 2014. PLoS ONE11: e0153379. doi:10.1371/journal.pone. 0153379

Matsuno K. (2014) Spatial and temporal changes in the plankton community in the western Arctic Ocean. Mem. Fac. Fish. Sci., Hokkaido University, 56: 65-107

Matsuno K., Ichinomiya M., Yamaguchi A., Imai I., Kikuchi T. (2014) Horizontal distribution of microprotist community structure in the western Arctic Ocean during late summer and early fall of 2010. Pol. Biol. 37: 1185-1195

Neeley A. R., Harris L. A., Frey K. E. (2018) Unraveling phytoplankton community dynamics in the northern Chukchi Sea under sea-ice-covered and sea-ice-free conditions. Geophys. Res. Lett. 45: 7663-7671

Spear A., Duffy-Anderson J., Kimmel D., Napp J., Randall J., Stabeno P. (2019) Physical and biological drivers of zooplankton communities in the Chukchi Sea. Pol. Biol. 42: 1107-1124

Zhang W., Feng M., Yu Y., Zhang C., Xiao T. (2019) Vertical distribution of oceanic tintinnid (Ciliophora: Tintinnida) assemblages from the Bering Sea to Arctic Ocean through Bering Strait. Pol. Biol., 42: 2105-2117

Wang C., Li H., Xu Z., Zheng S., Hao Q., Dong Y., Zhao L., Zhang W., Zhao Y., Grégori G., Xiao T. (2020) Difference of planktonic ciliate communities of the tropical West Pacific, the Bering Sea and the Arctic Ocean. Acta Oceanol. Sin., 39: 9-17

Wang Y., Kang J., Xiang P., Wang W., Lin M. (2020) Short timeframe changes of environmental impacts on summer phytoplankton in the Chukchi Sea and surrounding areas in a regional scaling. Ecological Indicators 117: 106693

Wuchang Z., Meiping F., Ying Y., Cuixia Z., Tian X. (2012) An Illustrated Guide to Contemporary Tintinnids in the World. Beijing: Science Press, 499 pp

Xu G., Yang E., Jiang Y., Cho K. H., Jung J., Lee Y., Kang S. H. (2018) Can pelagic ciliates indicate vertical variation in the water quality status of western Arctic pelagic ecosystems? Mar. Poll. Bull. 133: 182-190

Yang E. J., Ha H. K., Kang S. H. (2015) Microzooplankton community structure and grazing impact on major phytoplankton in the Chukchi sea and the western Canada basin, Arctic ocean. Deep Sea Res. Part II 120: 91-102

Yokoi N., Matsuno K., Ichinomiya M., Yamaguchi A., Nishino S., Onodera J., Inoue J., Kikuchi T. (2016). Short-term changes in a microplankton community in the Chukchi Sea during autumn: consequences of a strong wind event. Biogeosciences, 13: $913-923$

Received on $5^{\text {th }}$ April, 2021; revised on $17^{\text {th }}$ May, 2021; accepted on $24^{\text {th }}$ May, 2021 